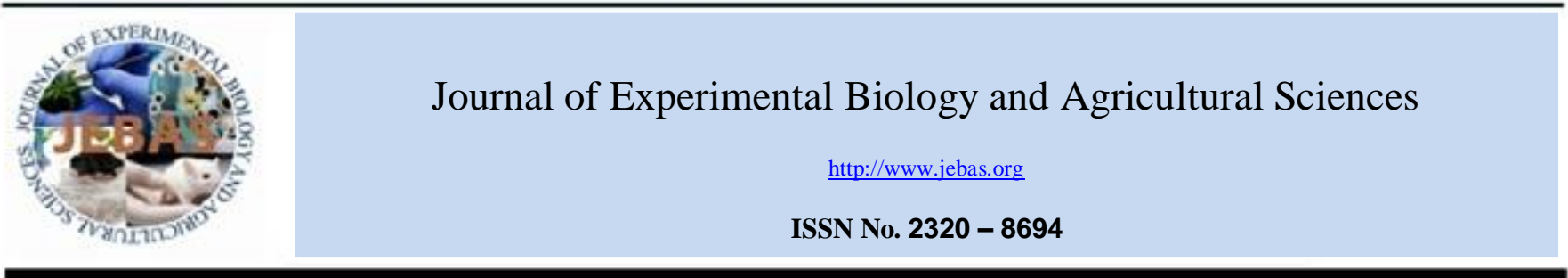

\title{
ALLEVIATION OF ANTI-NUTRITIVE COMPONENTS OF BAMBOO SHOOT THROUGH FERMENTATION
}

\author{
Mayanglambam Chandrakumar Singh ${ }^{1}$, Siddhartha Singh $^{1 *}$, Amit Kumar Singh ${ }^{1}$, \\ Pramod Kumar Pandey ${ }^{1}$, Lakidon Khonglah ${ }^{2}$, Brijesh Kumar Singh ${ }^{1}$, Ajai Kumar Pandey ${ }^{3}$ \\ ${ }^{1}$ Department of Basic Sciences \& Humanities, College of Horticulture \& Forestry, Central Agricultural University, Pasighat - 791102 \\ ${ }^{2}$ Department of Fruit Science, College of Horticulture \& Forestry, Central Agricultural University, Pasighat -791102 \\ ${ }^{3}$ Department of vegetable science, College of Horticulture \& Forestry, Central Agricultural University, Pasighat - 791102
}

Received - November 04, 2018; Revision - January 06, 2019; Accepted - March 18, 2019

Available Online - April 10, 2019

DOI: http://dx.doi.org/10.18006/2019.7(2).128.137

\section{KEYWORDS}

Adi Tribe

Anti nutritive Factors

Bamboo shoot

Fermentation

Nutraceuticals

\begin{abstract}
The increasing trends of health consciousness among consumers have stimulated the field of functional foods. The plant based functional foods or food constituents have been investigated for their role in disease prevention and have dazzled the scientific community with its potentiality and "Bamboo" is one of them. Bamboo is not popular as food but is consumed fresh, fermented or canned. The young shoots are rich in nutrients and nutraceuticals which make it an important food with numerous health benefits. Keeping in view the unexplored and unutilized potential of bamboo shoot as food, an attempt has been made for biochemical profiling of raw bamboo shoot and its fermented product. An increase in non reducing sugar, total starch and cellulose content was observed in the fermented product whereas a significant decrease in anti- nutritive factors phytic acid, tannins and cyanogens was observed as a result of fermentation. The decreases in anti- nutritive factors suggest that fermented products are more suitable for consumption.
\end{abstract}

* Corresponding author

E-mail: siddharthasingh786@gmail.com (Siddhartha Singh)

Peer review under responsibility of Journal of Experimental Biology and Agricultural Sciences.

Production and Hosting by Horizon Publisher India [HPI] (http://www.horizonpublisherindia.in/).

All rights reserved.
All the article published by Journal of Experimental Biology and Agricultural Sciences is licensed under a Creative Commons Attribution-NonCommercial 4.0 International License Based on a work at www.jebas.org.

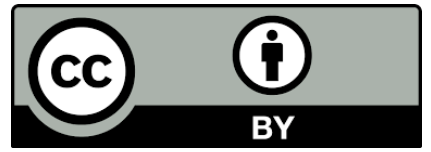




\section{Introduction}

Bamboo is the member of the family Poaceae which is almost ubiquitous. More than 1250 species within 75 genera have been reported worldwide, of which 125 species belonging to 23 genera have been reported from India (Satya et al., 2010; Satya et al., 2012) which is also one of the leading country having bamboo covered area accounting for $12.8 \%$ of the total forest cover (Biswas, 1994). North East India comprises of eight states with different ethnic groups of diverse populations. Bamboo variously known as "the cradle to coffin plant", "poor man's timber", "green gasoline", "green gold", etc. is deep rooted in multifarious form within the culture and tradition of the North- Eastern Indian people (Nirmala et al., 2011). It is used as food, medicine, fuel, shelters, hunting, handicraft, etc. by the people of the region (Sharma \& Borthakur, 2008). Bamboo shoots are rich in amino acids, antioxidants, minerals, glucose, low in fat, is brittle, tender, delicious and nutritive ( Sonar et al., 2015). Despite of its nutritive value, acceptability of bamboo shoot as the popular vegetable crop is very less due to its high pungent and bitter acidic taste which is attributed to the anti- nutritional components like cyanogenic glycoside, taxiphyllin [2-( $\beta$-D-glucopyranosyloxy- 2 (4- hydroxyphenyl) acetonitrile (Vetter, 2000). Hence, the bamboo shoots are generally boiled for $8-10$ minutes before consumption (Choudhury et al., 2011). Cyanogenic glycosides are inherently produced as a defense arsenal and are abundantly present in bamboo shoot in the form of taxiphyllin (Sayanika et al, 2013). Excessive intake of cyanogenic glycosides is life threatening and significantly associated with neurological disorder called Konzo (Nzwalo \& Cliff, 2011). The cyanogenic glycosides produce in bamboo shoot is broken down to sugars \& cyanohydrins and the latter readily decompose to give rise to hydrogen cyanide and an aldehyde or ketone (Moller \& Seigler, 1999). Fermentation has been reported as one of most economical and effective way of reducing the anti- nutritional component of bamboo shoot (Sarangthem \& Singh, 2013).

Arunachal Pradesh, the biodiversity hot spot of North-East India is inhabited by many different major tribes with many different ethnicities. Among them, Adi tribe is a major tribe inhabited in different districts like East Siang, West Siang, Lower Dibang Valley, etc. They are densely populated in the nearby districts of the mighty Siang River (Figure 1). The Adi tribes in Arunachal Pradesh uses banana leaves for semi fermentation of shoots and press it under stones in the water steam for the period of 3-4 months to reduce the bitterness (Satya et al., 2010). Traditional method of fermentation involved chopping of raw bamboo shoots into very small pieces and placing it in an air tight plastic container. The fermentation was found to be most effective in reducing some harmful biochemical components. Adi tribe widely uses bamboo shoot in almost every dish as fermented or raw or as dried called eyup because of its delicate flavor and is a chief component of Arunachal Pradesh food (Choudhury et al., 2012). It is the main ingredient without which their food would be left incomplete. Bamboo shoots are used in the dishes of boiled vegetables, cooked meat, pickles and chutneys. Dishes like lukter, ammin, etc are added to bamboo shoot for enhancement of flavor. Dishes with bamboo shoots have no particular ethnic names but many dishes are served on tables where bamboo shoot is an ingredient.

Present study focused on the quantitative changes occurring in the biochemical components of the product during fermentation. Scientific standardization of the traditional fermentation technique will help in increasing nutritional status of the bamboo shoot.

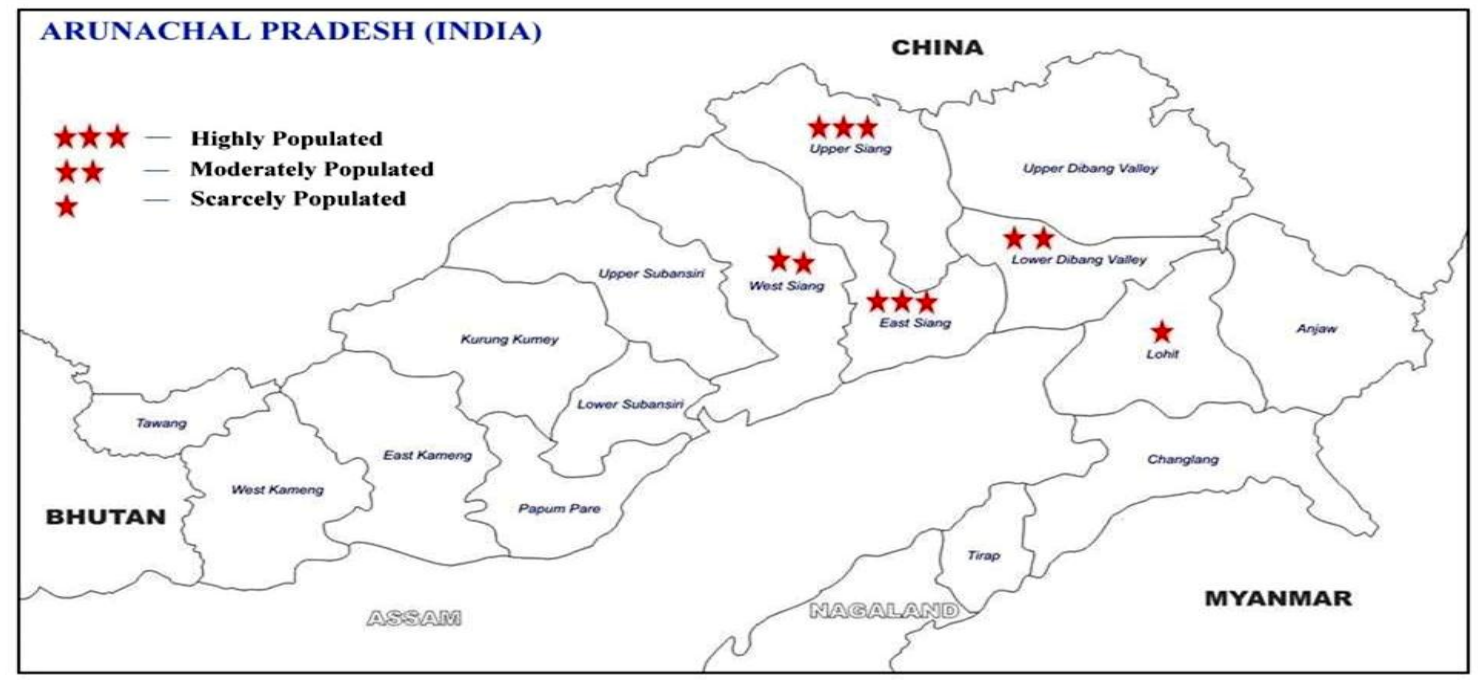

Figure 1 Map of Arunachal Pradesh showing Adi inhabited districts of Arunachal Pradesh

Journal of Experimental Biology and Agricultural Sciences

http://www.jebas.org 


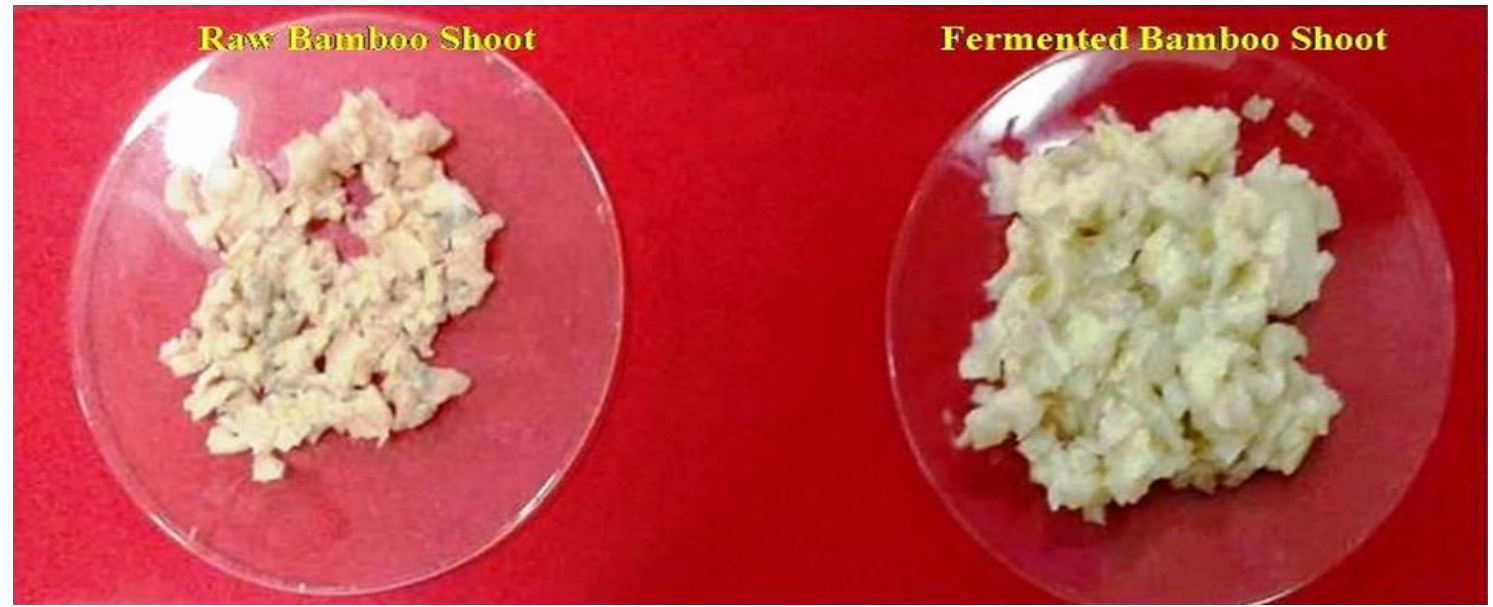

Figure 2 Chopped raw bamboo shoot and fermented bamboo shoot.

\section{Materials and Methods}

\subsection{Experimental material}

Fresh bamboo shoots purchased from the local market of Pasighat Town, East Siang District of Arunachal Pradesh, were chopped into small pieces and were kept in plastic bottles for fermentation. Fresh and fermented bamboo shoots (Figure 2) were used for the experiment.

\subsection{Biochemical profiling}

\subsubsection{Total Carbohydrates}

The total carbohydrate was estimated by the method of Hedge \& Hofreiter (1962). For this, $100 \mathrm{mg}$ sample was hydrolyzed on boiling water bath for $3 \mathrm{hrs}$ with $5 \mathrm{ml}$ of $2.5 \mathrm{~N} \mathrm{HCl}$, this mixture was neutralized with sodium carbonate. For analysis, $0.2 \mathrm{ml}$ of filtrate was taken in test tube and intensity of dark green colour was measured at $630 \mathrm{~nm}$ against a reagent blank.

\subsubsection{Starch}

Starch content was determined by the method of Hedge \& Hofreiter (1962). Sample (500mg) was homogenized in $80 \%$ hot ethanol, centrifuged and residue was collected. This residue dried over a water bath and dissolved in $5 \mathrm{ml}$ of water followed by addition of $6.5 \mathrm{ml}$ of $52 \%$ perchloric acid and incubation at $0^{\circ} \mathrm{C}$ for 20 minutes. The content was centrifuged at $3000 \mathrm{rpm}$ for 5 minutes. Rest of the procedure is similar to the estimation of total carbohydrates.

\subsubsection{Reducing Sugar}

Reducing sugar was determined by the method described by Somogyi (1952). For this $100 \mathrm{mg}$ sample was macerated with 5 $\mathrm{ml}$ of hot $80 \%$ ethanol and the content was centrifuged at 3000 rpm for 5 minutes. The obtained precipitate was dissolved in distilled water. An aliquot of $0.2 \mathrm{ml}$ was taken and diluted to $2 \mathrm{ml}$ distilled water and $1 \mathrm{ml}$ of alkaline copper tartarate reagent was added to each tube. The tube was placed in boiling water for 10 minutes. The tube was allowed to cool down; this was followed by the addition of $1 \mathrm{ml}$ of arsenomolybolic acid reagent. The content was incubated for 10 minutes at room temperature and observation was taken against the blank solution at $620 \mathrm{~nm}$.

\subsubsection{Estimation of Non Reducing Sugar}

Non reducing sugar was calculated by subtracting reducing sugar from total carbohydrate and then multiplying it by a factor of 0.95 .

\subsubsection{Crude Fibre}

Crude fibre content was determined by the method described by Maynard (1970). 2 gram of defatted sample was boiled in $20 \mathrm{ml}$ of $0.26 \mathrm{~N}$ sulphuric acid for 30 minutes. The sample was filtered and the filtrate was boiled with $20 \mathrm{ml}$ of $\mathrm{NaOH}$ solution for 30 minutes. This was followed the washing of filtrate with $1.25 \%$ sulphuric acid, $50 \mathrm{ml}$ distilled water and $25 \mathrm{ml}$ alcohol. Filtrate was removed and transferred to ashing dish. The residue was dried for 2 hours at $130^{\circ} \mathrm{C}$. Then the filtrate was cooled in a desiccator and weight was taken. After weighing the filtrate was ignited for 30 minutes at $600 \pm 15^{\circ} \mathrm{C}$, cooled in a desiccator and the weight was recorded.

\subsubsection{Cellulose}

Cellulose content was determined by the method of Updegroff (1969). For this $3 \mathrm{ml}$ of acetic/nitric reagent $(150 \mathrm{ml}$ of $80 \%$ acetic acid and $15 \mathrm{ml}$ of concentrated nitric acid) was added to $1 \mathrm{~g}$ 
of the sample and mixed well with the help of vortex mixture. Tubes were placed in water bath at $100{ }^{\circ} \mathrm{C}$ for 30 minutes. The content was cooled and centrifuged at $3000 \mathrm{rpm}$ for 15 minutes. The residue was collected and $10 \mathrm{ml}$ of $67 \%$ sulphuric acid was added to the residue. One $\mathrm{ml}$ of this diluted sample was mixed with $10 \mathrm{ml}$ of anthrone reagent. The tubes were placed in boiling water bath for 10 minutes. It was cooled and read against the blank solution at $630 \mathrm{~nm}$.

\subsubsection{Pectin}

Pectin content of raw bamboo shoot and its fermented product was estimated as per the methods given by Sadasivam \& Manickam (2008). Ten gm of sample was boiled with $60 \mathrm{ml}$ of $0.01 \mathrm{~N} \mathrm{HCl}$ for $30 \mathrm{~min}$ and filtered under the suction. Obtained residue was washed with hot water and boiled with $20 \mathrm{ml}$ of $0.05 \mathrm{~N} \mathrm{HCl}$ for $20 \mathrm{~min}$. The filtrate were pooled and the final volume was made up to $100 \mathrm{ml} .30 \mathrm{ml}$ filtrate was taken in $250 \mathrm{ml}$ beaker and neutralized with $1 \mathrm{~N} \mathrm{NaOH}$ using phenolphthalein indicator. Excess of $1 \mathrm{~N} \mathrm{NaOH}$ was added with constant stirring and allowed it to stand overnight. About $50 \mathrm{ml}$ of Acetic acid $(1 \mathrm{~N})$ was added and after five min, $25 \mathrm{ml}$ of $1 \mathrm{~N}$ calcium chloride solution was added with stirring and allowed to stand for one hour, boiled for two minutes and filtered through a pre-weighed Whatman No.1 filter paper. The precipitate washed with boiling water until the filtrate became free from chloride (tested the filtrate with silver nitrate for chloride). The filter paper with the calcium pectate was dried overnight at $100{ }^{\circ} \mathrm{C}$ in a weighing dish, cooled in a desiccator and weighed. Amount of pectin was estimated using the formula:

$\operatorname{Pectin}(\%)=\frac{(\text { Wt.of filter paper with sample }-\mathrm{Wt} . \text { of filter paper }) \times 500 \times 100}{\text { Volume of filtrate used }(\mathrm{ml}) \times \mathrm{Wt} . \text { of sample }}$

\subsubsection{Free fatty acid}

Free fatty content was determined by the method described by Cox \& Pearson (1962). For this, $1 \mathrm{~g}$ of the sample was ground in $50 \mathrm{ml}$ of the neutral solvent. Few drops of $1 \%$ phenolphthalein indicator were added in the sample and the sample was titrated against $0.1 \mathrm{~N}$ potassium hydroxide with continuous shaking until a pink colour appeared which persist for $10-15$ seconds. Free fatty acid was calculated as oleic acid using the equation:

Acid value (mg KOH/g)

$$
=\frac{\text { Titre value } \mathrm{x} \text { Normality of } \mathrm{KOH} \times 56.1}{\text { Weight of the sample }(\mathrm{g})}
$$

\subsubsection{Protein Content}

One gram of bamboo sample was homogenized in $5 \mathrm{ml}$ of phosphate buffer $(0.2 \mathrm{M}, \mathrm{pH} 7.2)$ and centrifuged at $8000 \mathrm{rpm}$ for 20 minutes under cold conditions. The supernatant was collected and protein content was estimated by the method as given by Lowry et al (1951).

\subsubsection{Total Free Amino acids}

Total free amino acid content was determined by the method described by Moore \& Stein (1948). Bamboo sample ( $0.5 \mathrm{~g}$ ) was ground with the help of mortar and pestle and $10 \mathrm{ml}$ of $80 \%$ ethanol was added to the homogenate. The content was filtered and filtrate was collected. $1 \mathrm{ml}$ of Ninhydrin solution was added to $0.1 \mathrm{ml}$ of aliquot and volume was made up to $2 \mathrm{ml}$ with distilled water. Tube was placed in boiling water bath for 20 minutes. Tube was allowed to cool down and $5 \mathrm{ml}$ of dilute solvent was added to each tube. After 15 minutes sample was read against the blank solution at $570 \mathrm{~nm}$.

\subsection{Ascorbic acid}

The ascorbic acid content was determined by the method described by Jagota \& Dani (1982). For this, $2 \mathrm{~g}$ of bamboo sample was ground with equal volume of $6 \%$ metaphosphoric acid and centrifuged at $5000 \mathrm{rpm}$ for 10 minutes then filtered through Whatman No. 1 filter paper. An aliquot of the sample extract $(0.1 \mathrm{ml})$ was diluted to $1.2 \mathrm{ml}$ with $3 \%$ metaphosphoric acid and final volume was made up to $4 \mathrm{ml}$ with distilled water. To each tube $0.4 \mathrm{ml}$ Folin-ciocalteau was added and mixed well. The tubes were incubated for 10 minutes at room temperature and centrifuged at $3000 \mathrm{rpm}$ for 10 minutes. After centrifugation, supernatant was read against the blank solution at $760 \mathrm{~nm}$. The ascorbic acid content $(\mathrm{mg} / 100 \mathrm{~g})$ was calculated using the formula:

$$
\text { Vit.C }\left(\frac{\mathrm{mg}}{100 \mathrm{~g}}\right)=\frac{\text { Total volume of the sample } \mathrm{x} \text { Conc.of the Vit.C } \times 100 \times 1}{\text { Weight of sample } \mathrm{x} \text { Amount of sample } \mathrm{x} 1000}
$$

\subsubsection{Thiamine}

Thiamine content was determined by the method described by Sadasivam \& Manickam (2008). Five gram of finely ground bamboo sample was taken in to $250 \mathrm{ml}$ conical flask. $0.1 \mathrm{~N}$ sulphuric acid was added slowly without shaking and was incubated overnight. From this, $10 \mathrm{ml}$ of extract was pipetted out, in this $3 \mathrm{ml}$ of $15 \% \mathrm{NaOH}$ was added to each separating funnel followed by $3-4$ drops of ferricyanide solution. $15 \mathrm{ml}$ of isobutanol was added rapidly from a measuring cylinder. Separating funnel was shaken vigorously for 60 seconds and allowed to develop layers. Bottom layer was drained out. One spatula full sodium sulphate was added directly into the separating funnel and was gently swirled to clarify the extract. The clear extract from top layer was pipetted out into a clean test tube. Series of blank sample was prepared by pipetting out $10 \mathrm{ml}$ of the extract and the above procedure was followed but addition of ferricyanide was omitted. The extract was read against the blank solution at $366 \mathrm{~nm}$. 


\subsubsection{Vitamin E}

The vitamin E content was determined by the method described by Rosenberg (1992). Five gram (0.5 g) bamboo sample weighed and homogenized. $10 \mathrm{ml}$ of $0.1 \mathrm{~N}$ sulphuric acid was added and allowed to stand overnight. The content was filtered through Whatman No. 1 filter paper. From this, $1.5 \mathrm{ml}$ of standard tissue extract and water were taken in 3 different test tubes. $1.5 \mathrm{ml}$ of ethanol was added to test and this was followed by the addition of $1.5 \mathrm{ml}$ of xylene to each tube and centrifugation. $1 \mathrm{ml}$ of xylene layer was transferred to another tube and $1.0 \mathrm{ml}$ of 2,2'-dipyridyl reagent was added to it. The test and standard mixture was read at $460 \mathrm{~nm}$ against the blank. $0.33 \mathrm{ml}$ of ferric chloride was added to each tube and supernatant was read against the blank solution at $520 \mathrm{~nm}$ exactly after 15 minutes.

\subsubsection{Phenols}

Phenol content was determined by the method given by Malick \& Singh (1980). Collected sample (1 g) was homogenized in $10 \mathrm{ml}$ of $80 \%$ ethanol. The content was centrifuged at $10000 \mathrm{rpm}$ for 20 minutes. Supernatant was collected and evaporated to dryness. Water $(5 \mathrm{ml})$ was added to dissolve the residue. An aliquot of $0.2 \mathrm{ml}$ were taken and diluted to $3 \mathrm{ml}$ with distilled water. $0.5 \mathrm{ml}$ of Folin-Ciocalteau reagent was added to each tube followed by addition of $2 \mathrm{ml}$ of $20 \% \mathrm{Na}_{2} \mathrm{CO}_{3}$ after 3 minutes. The tube was allowed to cool down and sample was read at $650 \mathrm{~nm}$ against the blank solution sample.

\subsubsection{Tannins}

Tannin content was determined by the method described by Schanderl (1970). Sample (0.5 g) was transferred to a $250 \mathrm{ml}$ conical flask and $75 \mathrm{ml}$ water was added. The flask was gently heated and boiled for 30 minutes. The flask was centrifuged at $2000 \mathrm{rpm}$ for 20 minutes. Supernatant was collected in volumetric flask and final volume was diluted with distilled water to $100 \mathrm{ml} .1 \mathrm{ml}$ of the sample extract was transferred to $100 \mathrm{ml}$ volumetric flask containing $75 \mathrm{ml}$ water. $5 \mathrm{ml}$ of FolinDenis reagent and $10 \mathrm{ml}$ of sodium carbonate solution was added and diluted to $100 \mathrm{ml}$ with water. Sample was mixed well and after 30 minutes, the content was read against the blank solution at $700 \mathrm{~nm}$.

\subsubsection{Phytic acid}

Phytic acid was determined by the method described by Wheeler \& Ferrel (1971). One gram of finely ground sample was dissolved in $50 \mathrm{ml}$ of $3 \%$ TCA and incubated for 30 minutes with continuous stirring. The content was centrifuged and supernatant was collected. $10 \mathrm{ml}$ of aliquot was mixed with $4 \mathrm{ml}$ of $\mathrm{FeCl}_{3}$ solution and was incubated for 45 minutes on a hot water bath. The content was centrifuged for 5 minutes and precipitate was collected and was washed with $20 \mathrm{ml}$ of 3 $\%$ TCA, incubated on boiling water bath for 10 minutes and was centrifuged again for 15 minutes at $3000 \mathrm{rpm}$. Precipitate was dispersed in $2 \mathrm{ml}$ of water and $3 \mathrm{ml}$ of $1.5 \mathrm{~N} \mathrm{NaOH}$ was added to it. The sample was filtered and precipitate was dissolved in $40 \mathrm{ml}$ hot $3.2 \mathrm{~N} \mathrm{HNO}_{3}$ in a conical flask. $5 \mathrm{ml}$ of aliquot was transferred to another conical flask and the volume was made up to $70 \mathrm{ml}$ with distilled water. $20 \mathrm{ml}$ of $1.5 \mathrm{M}$ potassium thiocyanate was added and after 1 minute the sample was read against the blank solution at $480 \mathrm{~nm}$.

\subsubsection{Cyanogen}

Cyanogen content was determined by the method described by Hogg \& Ahlgren (1942). For this, $1 \mathrm{~g}$ of the sample was homogenized in $25 \mathrm{ml}$ of water with 3-4 drops of chloroform. Paper was cut into strips and was placed in alkaline picrate solution. Saturated filter paper was placed in hanging position with the help of a cork stopper inside the conical flask. The sample was kept for overnight. Colour was eluted by placing the saturated filter paper in a clean test tube containing 10 $\mathrm{ml}$ of distilled water. Sample was read at $625 \mathrm{~nm}$ against a reagent blank.

\subsection{Statistical analysis}

All experiments were performed in triplicate, differences among control and fermented samples were analysed by OneWay ANOVA (Panse \& Sukhatme, 1984). Asterisks were used to identify the level of significance $(\mathrm{p} \leq 0.05)$ of the difference between control and fermented product.

\section{Results}

Present study was conducted to assess the biochemical parameters of bamboo shoot and its traditionally fermented products consumed by Adi tribes of Arunachal Pradesh, very interesting and factual results were obtained. The analysis of variance revealed significant variation between raw and fermented bamboo shoots for all the analyzed biochemical parameters (except crude fiber, total soluble protein, Vitamin E and titrable acidity) at 5\% critical level. An overall reduction in biochemical components were observed after fermentation. Carbohydrates, an ideal source of energy was found to decrease from $16.46 \mathrm{~g} / 100 \mathrm{~g}$ (raw bamboo shoot) to 
$10.76 \mathrm{~g} / 100 \mathrm{~g}$ (fermented bamboo shoot) (Table 1). Similar pattern was observed in reducing sugar content and the fermented product exhibit a decrease of $28.4 \%$. However, an increase in non reducing sugar, starch and cellulose content was observed after fermentation (Table 1). No significant change was observed in crude fibre content. Further, free fatty acids are nutritionally important as it helps in proper functioning of liver, cell membrane synthesis, etc. The fermented product was found to contain lower concentration of free fatty acids with a decrease of $47.48 \%$ on fermentation.

An increase in total soluble protein content on fermentation was observed but the total free amino acid concentration was found to decrease in fermented product $(0.62 \mathrm{~g} / 100 \mathrm{~g})$ as compared to fresh bamboo shoot (1.24 g/100g) (Table 1). Thiamine, ascorbic acid and Vitamin E content were also estimated. A $75 \%$ and $50 \%$ decrease in ascorbic acid and thiamine concentration was observed after fermentation respectively but surprisingly there was no such change observed in case of Vitamin E (Table 1). A two fold increase in total titrtable acidity was observed whereas an increase of $15 \%$ was observed in case of pectin.

Fermentation leads to decrease in concentration of nearly all the anti-nutritive factors. A huge decrease of $62.5 \%$ was observed for cyanogens (Figure 3,4) whereas a decrease of $70 \%$ and $44.83 \%$

Table 1 Nutritive components of raw bamboo shoot and its fermented product

\begin{tabular}{|c|c|c|c|c|}
\hline Biochemical components & Raw bamboo shoot & Fermented product & $\mathrm{CD}(\mathrm{P}=0.05)$ & $\operatorname{SE}(d)$ \\
\hline Total carbohydrate $(\mathrm{g} / 100 \mathrm{~g})$ & $16.46 \pm 0.04$ & $10.76 \pm 0.06$ & 0.646 & 0.277 \\
\hline Reducing sugar $(\mathrm{g} / 100 \mathrm{~g})$ & $2.43 \pm 0.06$ & $1.74 \pm 0.03$ & 0.04 & 0.014 \\
\hline Non reducing sugar $(\mathrm{g} / 100 \mathrm{~g})$ & $7.49 \pm 0.06$ & $13.25 \pm 0.04$ & 0.672 & 0.236 \\
\hline Total starch $(\mu \mathrm{g} / \mathrm{g})$ & $4.68 \pm 0.05$ & $8.91 \pm 0.04$ & 0.066 & 0.023 \\
\hline Cellulose $(\mu \mathrm{g} / \mathrm{g})$ & $1.73 \pm 0.02$ & $3.14 \pm 0.02$ & 0.038 & 0.013 \\
\hline Crude fibre (\%) & $5.0 \pm 0.1$ & $4.95 \pm 0.06$ & NS & 0.014 \\
\hline Pectin $(\%)$ & $70 \pm 0.2$ & $82.5 \pm 0.05$ & 0.381 & 0.134 \\
\hline Free fatty acid $(\mathrm{mg} / 100 \mathrm{~g})$ & $4.76 \pm 0.12$ & $2.5 \pm 0.05$ & 0.016 & 0.006 \\
\hline Total protein $(\mathrm{g} / 100 \mathrm{~g})$ & $0.017 \pm 0.001$ & $0.024 \pm 0.002$ & NS & 0.005 \\
\hline Total free amino acid $(\mathrm{g} / 100 \mathrm{~g})$ & $1.24 \pm 0.06$ & $0.62 \pm 0.04$ & 0.016 & 0.006 \\
\hline Thiamine $(\mathrm{mg} / 100 \mathrm{~g})$ & $1.5 \pm 0.05$ & $0.75 \pm 0.03$ & 0.114 & 0.04 \\
\hline Ascorbic acid(mg/100g) & $2.42 \pm 0.06$ & $0.66 \pm 0.02$ & 0.096 & 0.034 \\
\hline Vitamin E (mg/100g) & $0.48 \pm 0.03$ & $0.48 \pm 0.04$ & NS & 0.016 \\
\hline Tritrable acidity (Acetic acid) (\%) & $0.06 \pm 0.004$ & $0.12 \pm 0.25$ & NS & 0.003 \\
\hline Total phenols $(\mu \mathrm{g} / \mathrm{g})$ & $25.4 \pm 0.05$ & $7.6 \pm 0.1$ & 2.101 & 0.737 \\
\hline
\end{tabular}

Values are mean values $\pm \mathrm{SD}$ from three replications

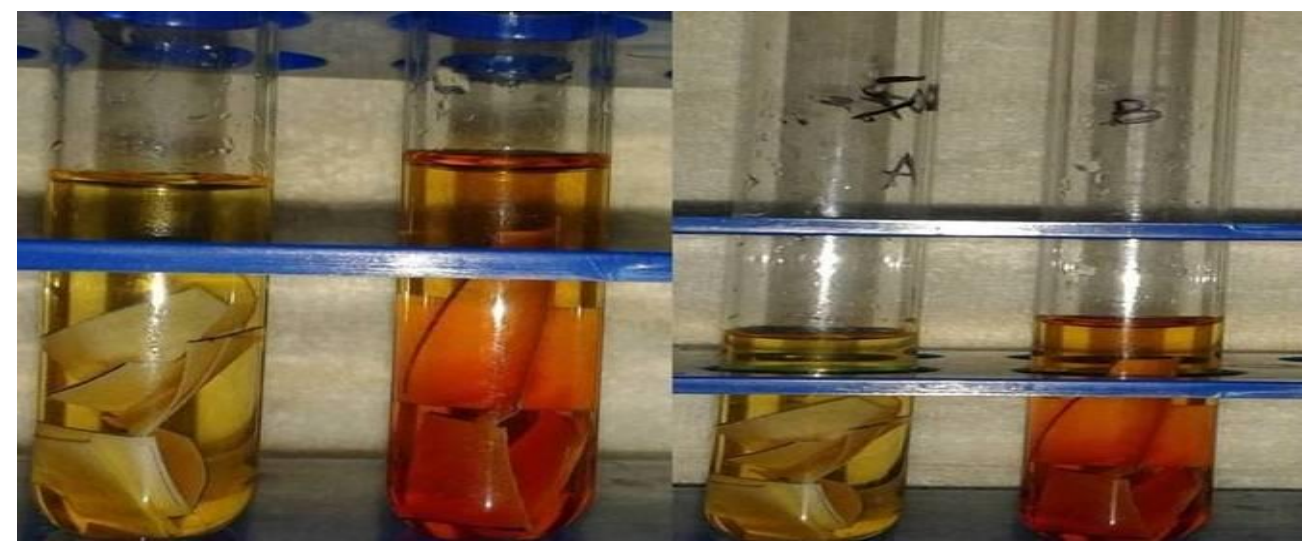

Figure 3 Hydrogen cyanide production by (A) Fermented bamboo shoot (B) Raw bamboo shoot

Journal of Experimental Biology and Agricultural Sciences http://www.jebas.org 


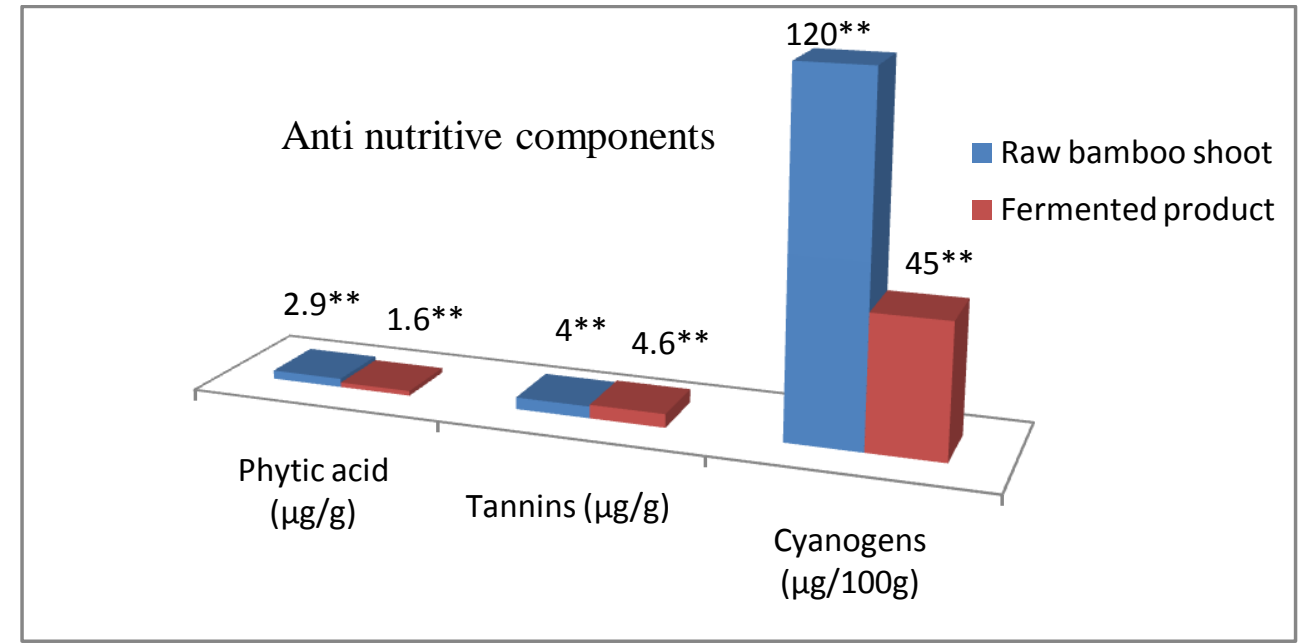

Figure 4 Effect of fermentation on anti nutritional components of Bamboo shoot. (** represents significant at $\quad \mathrm{p} \leq 0.05$ )

was observed in case of total phenols and phytic acid respectively (Figure 4), however, a slight increase of nearly $13 \%$ was observed in case of tannins (Figure 4)

\section{Discussion and Conclusion}

Fermentation is one of the most economical methods of fabricating and preserving food. It leads to improvement in the shelf life, texture, taste and aroma of the final product as well as reduces the toxic components. Fermentation of foods can be achieved through various manufacturing techniques, raw materials and microorganisms (Blandino et al., 2003). Fermented bamboo shoots are among the popular cuisines of North Eastern people. Bamboo shoots are low in calories, high in dietary fiber, and rich in various nutrients. Bamboo shoot is considered to be a good source of nutrients such as protein, carbohydrates, amino acids, minerals, fat, sugars, fiber and inorganic salts (Nirmala et al., 2011). Besides these beneficial components, it also possess some detrimental components such as cyanogens, phytic acid etc which are not good for health. Fermentation is one of the most economic and effective method for the reduction of these detrimental components (Sarangthem \& Singh, 2013). The Adi tribe of Arunachal Pradesh has been using the traditional fermentation process since time immemorial for making variety of cuisines from the fermented product.

Carbohydrates are the instant source of energy and have a wide range of beneficial effects on human health. These carbohydrates help in regulation of blood glucose, insulin, cholesterol and triglycerides metabolism, bile acid dehydroxylation, protein glycosylation, etc. Raw bamboo shoot was found to be a good source of energy with a value of $16.46 \mathrm{~g} / 100 \mathrm{~g}$ which shows a decrease on fermentation. Similarly, Nirmala et al. (2008) suggested that fermentation leads to decrease in total carbohydrate content of Dendrocalamus giganteus. The reduction in total carbohydrate content may be due to action of microbial $\alpha$ and $\beta$ amylases and its utilization as carbon source by the fermenting microbes.

Sugar helps in stimulation of the feel good hormone, the serotonin and is also linked to obesity, heart disease, cancer, severe PMS, dementia, and diabetes. Its limited consumption is essential requirement for a healthy life. A decrease in reducing sugar content and increase in non reducing sugar content of bamboo shoot was observed after fermentation. The decrease in reducing sugar may be due to its conversion to some other byproducts during the process of fermentation (Singh et al., 2011) or might be due to its utilization as carbon source by the fermenting microbes. The decrease in reducing sugar content is advantageous from a nutritional point of view as a high proportion of unassimilable raffinose and related sugars included in the fraction are reduced on fermentation. Increase in non reducing content on fermentation may be due to secretion by the fermenting microbes.

Cellulose increases the peristaltic movement of the intestine and helps in digestion process. The high cellulosic content in bamboo shoots stimulates appetite (Nirmala et al., 2011). A significant increase in the starch and cellulose content was also observed on fermentation. The increase in these polysaccharides may be due to secretion of exo-polysaccharides by the fermenting microbes or may be due to the termination of starch degradation by low $\mathrm{pH}$ which inhibits amylase activity and/or due to presence of tannins that inhibit amylotic enzymes.

Fibers are becoming one of the most appreciated ingredients in today's diet (Nirmala et al., 2011). Bamboo shoots are a rich 
source of dietary fiber (Nirmala et al., 2008). Pectin is a structural polysaccharide which is used for high cholesterol, high triglycerides, for prevention of colon cancer and prostate cancer. Pectin content in the fermented product is enough to carry out all its physiological activities.

Bamboo shoots are taken as an ideal food, for providing healthy nutrition to people with diabetic and cardio thoracic diseases because of its low fat content (Nongdam \& Tikendra, 2014). Reduction in fatty acid content was observed which may be due to its utilization as a substrate for energy production by the fermenting microbes.

The protein content was found to be very less; however, an improvement was recorded in the fermented product. The less quantity of soluble protein may be due to its denaturation at higher temperature and altered $\mathrm{pH}$, and the increase in protein content may be due to presence of microbial proteins in the fermented product. The loss of free amino acids may be due to leaching or may be due to reaction with sugars to form complexes (Meredith \& Dull, 1979). Increase in sourness of fermented product may be because of the increase in acetic acid content.

Consumption of bamboo shoot is recommended as it is rich in thiamine content which is very much essential for maintenance of healthy metabolism. Vitamin E, the fat soluble vitamin possess several health benefits such as vision improvement, hormonal balance, disease prevention, cholesterol level control, etc. whereas, its deficiency leads to poor transmission of nerve impulses, muscle weakness and degradation of the retina that causes blindness, etc.

A $75 \%$ and $50 \%$ decrease in ascorbic acid and thiamine concentration was observed after fermentation but surprisingly there was no such change observed in case of Vitamin E. The decrease in ascorbic acid may be due to increased activity of the enzyme ascorbate oxidase that might have been produced by the fermentation microorganism which strongly depends on the $\mathrm{pH}$ of the fermentation environment. The enzymes convert ascorbic acid to dehydroascorbic acid (Adetuyi et al., 2008).

Bamboo shoots are promising source of phenolic oxidants and angiotensin converting enzyme (Park \& Jhon, 2010). Decrease in the content of the total phenols may be due to the diffusion of phenolics in cell liquids and oxidation of diffused phenolics by the action of an enzyme polyphenol oxidase (Adetuyi \& Ibrahim, 2014).

Bamboo shoot contains varying amount of cyanogenic glycosides called taxiphyllin (Vetter, 2000). The $\beta$ - glycosidase which released in disrupted tissues acts on taxiphyllin to produce harmful hydrogen cyanide. A case of cyanide poisoning of a 14 year old female with a history of consumption of bamboo shoot juice in JSS Hospital, Mysore, India was reported recently (Pramod Kumar et al., 2011) which confirms that hydrogen cyanide content of bamboo shoot can be highly detrimental to health. In present study, fermentation reduces the content of free cyanide drastically; suggesting that fermentation as an efficient technique for reduction of anti nutritive components. The decrease in cyanogens might be due to leaching or action of microbial enzymes. As a result of fermentation, an increase in tannin content was observed which could be attributed to hydrolysis of condensed tannins such as proanthocyanidin. Fermentation resulted in a decrease of $44.82 \%$ in phytic acid content. The decrease in phytic acid content may be attributed to microbial phytase which leads to degradation of phytic acid.

Different species of bamboo and their fermented products are used as food in different North Eastern states of India. Different techniques are also employed by the indigenous people of the region for the fermentation of bamboo shoot and interestingly these techniques differ from tribe to tribe. These techniques of fermentation are passed on from one generation to next generation without any standardization. Adi tribes of Arunachal Pradesh uses different species of bamboo for consuming as raw and fermented product without much knowledge of their nutritional status and anti- nutritional features. Moreover the importance of fermentation in reducing the content of cyanogenic glycoside and other components like phytic acid, tannins etc., of bamboo shoot. Many workers have reported the medicinal importance of bamboo shoots and different ways to decrease the content of cyanogenic glycoside which may lead to neurological disorders like Konzo after prolonged use of raw bamboo shoots. These scientific findings and reports for the better consumption of bamboo shoots must reach to the people of this region as these indigenous people use bamboo shoots as their main food source. Indigenous peoples of this region also use traditional techniques to reduce harmful components from bamboo shoot which needs to be standardized. It is also suggested that needs of awareness programmes become essential among the people for the importance of bamboo shoots and its harmful effect.

\section{Acknowledgement}

We are very much thankful to the Department of Biotechnology (DBT) for their financial support through IBT Hub (Grant no. BT/04/NE/2009), Department of Basic Science \& Humanities, College of Horticulture \& Forestry, CAU, Pasighat-791102, and Arunachal Pradesh. We are also very much thankful to Santosh Kumar Rai and Rita Sharma who manually helped us throughout this whole research works.

Conflict of Interest: All the authors have no conflict of interest 


\section{References}

Adetuyi FO, Ibrahim TA (2014) Effect of Fermentation Time on the Phenolic, Flavonoid and Vitamin C Contents and Antioxidant Activities of Okra (Abelmoschus esculentus) Seeds. Nigerian Food Journal $32: 128-137$.

Adetuyi FO, Osagie AU, Adekunle AT (2008) Antioxidant Degradation in six indigenous okra (Abelmoschus esculentus (L) Moench) varieties during storage in Nigeria. Journal of Food Technology 6: 227-230.

Biswas S (1994) Diversity and genetic resource of Indian bamboos and the strategies for their conservation. In: Rao VR, Rao AN (Eds.), Proceedings of the First Inbar Biodiversity. Singapore: Genetic Resources and Conservation Working Group. Pp. 29-34.

Blandino A, Al-Aseeri ME, Pandiella SS, Cantero D, Webb C (2003) Cereal based fermented foods and beverages. Food Research International 36: 527-543.

Choudhury D, Sahu JK, Sharma GD (2011) Bamboo shoot based fermented food products: a review. Journal of Scientific and Industrial Research 70: 199 - 203

Choudhury DB, Sahu JK, Sharma GD (2012) Bamboo shoot: Microbiology, Biochemistry and technology of fermentation - a review. Indian Journal of Traditional Knowledge 11:242-249.

Cox HE, Pearson D (1962) The Chemical analysis of foods. Chemical Publishing co. Inc., New York.

Hedge JE, Hofreiter BT (1962) Determination of reducing sugars and carbohydrates. In: Whistler RL, Wolfram ML (Eds.) Methods in Carbohydrate Chemistry, NY: Academic Press.

Hogg PG, Ahlgren HL (1942) A rapid method for determining hydrocyanic acid content of single plants of sudan grass. Journal of American Society of Agronomy 34: 199-200.

Jagota SK, Dani HM (1982) A new Colorimetric Technique for Estimation of Vitamin C using Folin - Phenol reagent. Annals of Biochemistry 127: 178-82

Lowry OH, Rosebrough NJ, Farr AL, Randall RJ (1951) Protein measurement with folin phenol reagent. Journal of Biological Chemistry 193:265- 275

Malick CP, Singh MB (1980) Plant enzymology and Histoenzymology. Kalyani publishers, New Delhi, Pp. 286

Maynard AJ (1970) Methods in food analysis. Academic Press, New York, Pp. 176.
Meredith F, Dull G (1979) Amino acid levels in canned sweet potatoes and snap beans. Journal of Food Technology 33: 55-57.

Moller BL, Seigler DS (1999) Biosynthesis of cyanogenic glycosides, cyanolipids and related compounds. In: Singh BK (Ed.), Plant amino acids biochemistry and biotechnology. Marcel Dekker.

Moore S, Stein WH (1948) Methods in Enzymology. Academic Press, New York, Pp. 468.

Nirmala C, Bisht MS, Sheena H (2011) Nutritional Properties of Bamboo Shoots: Potential and Prospects for Utilization as a Health Food. Comprehensive Reviews in Food Science \& Food Safety 10:153-165.

Nirmala C, Sharma ML, David E (2008) A comparative study of nutrient components of freshly harvested, fermented and canned bamboo shoots of Dendrocalamus giganteus Munro. Journal of American Bamboo Society 21 : 33-39.

Nongdam P, Tikendra L (2014) The Nutritional Facts of Bamboo Shoots and Their Usage as Important Traditional Foods of Northeast India. Inter Scholarly Research Notice Pp. 1-17.

Nzwalo H, Cliff J (2011) Konzo: from poverty, cassava, and cyanogen intake to toxico-nutritional neurological disease. PLOS Neglected Trop Disease 5:e1051.

Panse VG, Sukhatme PV (1984). Statistical methods for agricultural workers. ICAR, New Delhi.

Park EJ, Jhon DY (2010) The antioxidant, angiotensin- converting enzyme inhibition activity, and phenolic compounds of bamboo shoot extract. International Journal of Food Science \& Technology 43: 655-659.

Pramod Kumar GNP, Chandrakant HV, Annei JV, Manjunatha B, Balaraj BM, Sudharshan Murthy KA (2011) Bamboo shoot- is it edible or poisonous? Journal of the Indian Society of Toxicology 7: 19-21.

Rosenberg HR (1992) Chemistry and physiology of vitamins. Interscience publishers, Inc. New York, Pp. $452-453$

Sadasivam S, Manickam A (2008) Biochemical Methods. $3^{\text {rd }}$ edition. New Age International Publishers, New Delhi, India.

Sarangthem K, Singh TN (2013) Fermentation decreases the anti nutritional content in bamboo shoots. International Journal of Current Microbiology and Applied Science 2: 361-369.

Satya S, Bal LM, Singhal P, Naik SN (2010) Bamboo shoot processing: food quality and safety aspect (a review). Trends in Food Science \& Technology 21: 181-189. 
Satya S, Singhal P, Bal LM, Sudhakar P (2012) Bamboo shoot: a potential source of food security. Medical Journal of Nutrition and Metabolism 5: 1-10.

Sayanika DW, Bengyella L, Chandradev KS, Bharat GS, Singh MW, Narayan CT (2013) Grappling the high altitude for safe edible Bamboo shoots with rich nutritional attributes and escaping cyanogenic toxicity. Article ID 289285, 11 pages. http://dx.doi.org/10.1155/2013/289285.

Schanderl SH (1970) Methods in food Analysis. New York, Academic Press.

Sharma TP, Borthakur SK (2008) Enthnobotanical observations on bamboo among Adi tribes in Arunachal Pradesh. Indian Journal of Traditional Knownledge 7 : 594-597.

Singh AS, Singh DH, Nongmaithem R, Bora TC, Singh RN (2011) Comparative study of chemical properties of Soibum- A traditional fermented bamboo shoot product and its biological investigation. International Journal of Bioscience, Biochemistry. Bioinformatic 1:114-118.

Somogyi M (1952) Estimation of sugars by colorimetric method. Journal of Biological Chemistry 200: 245

Sonar NR, Vijayendra SVN, Prakash M, Saikia M, Tamang JP, Halami PM (2015) Nutritional and functional profile of traditional fermented bamboo shoot based products from Arunachal Pradesh and Manipur states of India. International Food Research Journal $22: 788-797$.

Updegroff DM (1969) Semi micro determination of cellulose in biological materials. Analytical Biochemistry 32: 420-424.

Vetter J (2000) Plant cyanogenic glycosides. Toxicon 38 : 11-36.

Wheeler EL, Ferrel RE (1971) A Method for Phytic Acid Determination in Wheat and Wheat Fractions. Cereal Chemistry 48 :312-320.

Journal of Experimental Biology and Agricultural Sciences

http://www.jebas.org 